\title{
Giorgio Agamben, Pulcinella, czyli Rozrywka dla dzieci [Pulcinella ovvero Divertimento per li regazzi], przeł. Joanna Ugniewska, Fundacja Augusta Hrabiego Cieszkowskiego, Warszawa 2019, ss. 200
}

DOI: http://dx.doi.org/10.12775/RF.2021.012

Giorgio Agamben - współczesny włoski filozof, którego polskiemu czytelnikowi nie trzeba specjalnie przedstawiać - to myśliciel, by tak rzec, szczególnego rodzaju. Po pierwsze, ze względu na tematykę pisarstwa filozoficznego, które uprawia. Utrzymana w postmodernistycznym duchu, nie tworzy ona wielopiętrowych konstrukcji złożonych z myśli i pojęć, lecz wprost przeciwnie. Agamben wybiera przeważnie jedną ideę jako osnowę swoich rozważań (nie da się ukryć, że idea, po którą najczęściej sięga filozof, jest idea potencjalności), a następnie, zestawiając ze sobą dobrze zadomowione w filozofii koncepcje, figury czy pojęcia, ustawia je w zaskakujące, iście neobarokowe, konstelacje, proponując zaskakujące i „niekanoniczne” odczytania problemów oraz rozwiązania starych aporii, z którymi pokolenia filozofów zmagają się niemal od zarania dziejów.

Przy czym należy dodać, że nieoczywisty, a nierzadko i kontrowersyjny w pisarstwie filozoficznym Agambena pozostaje nie tylko sposób, w jaki Włoch uprawia filozofię, a może zwłaszcza - „zasiedlanie” przez niego tych przestrzeni, o których nikt nigdy nie powiedziałby, że mogą w jakikolwiek sposób posłużyć jako figury czy motywy, które staną się twórcze i płodne do wysnucia oryginalnej i świeżej refleksji filozoficznej czy wręcz staną się nowymi toposami w filozofii.

W niewielkich rozmiarów monografii Pulcinella, czyli Rozrywka dla dzieci, która ukazała się nakładem Fundacji Augusta Hrabiego Cieszkowskiego w serii Miniatury Filozoficzne, widać obie te cechy twórczości Agambena. Z jednej strony mamy tu do czynienia z bardzo zręcznym i erudycyjnym poruszaniem się po tematyce zarówno filozoficznej, jak i literaturoznawczej czy nawet przynależącej do historii sztuki. Z drugiej strony zaś oryginalność myśli autora Homo sacer przejawia 
się także w specyficznym doborze tematyki. A jest nią, w przypadku omawianej książki... Pulcinella, czy jak utarło się mówić po polsku Poliszynel (polska wersja imienia pochodzi z języka francuskiego fr. Polichinelle).

Pulcinella to postać z commedia dell'arte, czyli z włoskiej komedii ludowej sięgającej połowy XVI wieku, która posługiwała się w swoich sztukach maskami. Nie wyklucza się także proweniencji francuskiej Pulcinelli - miałby on wówczas pochodzić z teatru kukiełkowego. Maska Poliszynela, postaci emblematycznej dla Neapolu, obok innych typowych dla komedii dell'arte postaci, jak na przykład Arlecchino czy Colombina, uosabiała, na co zwrócił uwagę Benedetto Croce, nie tyle konkretną postać, co ich zbiór - powiązanych ze sobą jedynie imieniem oraz zewnętrznymi atrybutami. Pisząc o komedii dell'arte, trzeba mieć na uwadze jeden fakt - choć narodziła się, jak zostało powiedziane, w czasach nowożytnych, jej korzenie sięgają rzymskiej komedii atellańskiej. Pulcinella znajduje bowiem swojego protoplastę w niejakim Maccusie - rzymskim prostaku i żarłoku (od jego imienia ma pochodzić słowo maccherone, to jest „makaron”), bohaterze niejednej ludowej farsy.

Pulcinella to mężczyzna nieco niesforny, gburowaty, powierzchowny i gadatliwy (stąd frazeologizm - "tajemnica Poliszynela”), a przy tym niestroniący od przyjemności życia. Ubrany na biało w powłóczystych szatach, za dużych pantalonach i niekiedy czerwonym swetrze przywdzianym na białą lnianą koszulę, z obwisłym stożkiem na głowie (tzw. coppolone), z przybraną na twarzy czarną "półmaską" z haczykowatym nosem - wzbudzał powszechny śmiech. Komizmu postaci przydaje zresztą same imię - Pulcinella jest zdrobnieniem (inna sprawa, że agramatycznie "przerobionym” na modłę żeńską) słowa pollo, czyli „kurczak”.

Tytuł książki Agambena, która we Włoszech ukazała się w listopadzie 2015 roku, nawiązuje do cyklu 104 późnorokokowych rysunków autorstwa Giovanniego Tiepolo, pochodzących z 1797 roku, który artysta poświęcił właśnie, nie wiedzieć czemu, Pulcinelli. Rok 1797, kiedy to ostatni doża wenecki, Ludovico Manin, abdykuje zmuszony żądaniami Napoleona Bonapartego, jest interesujący także z innego względu. W tym bowiem roku sędziwy już Tiepolo kończy inny cykl, tym razem fresków w podweneckiej rodzinnej willi w Zianigo. Freski - co nie umyka uwadze Agambena - powstają w niewielkim pomieszczeniu, w którym malarz prawdopodobnie dość długo przebywał. Tak jakby Pulcinella miał być ostatnim towarzyszem, z którym malarz decyduje się spędzić krótki czas, który mu pozostał (por. s. 9). Niczym Arystofanes wystawiający komedie podczas wielkiej wojny peloponeskiej - zamiast uwieczniać na ścianach i sufitach chwalebną przeszłość najdłużej istniejącej republiki w historii - maluje divertimento, "rozrywkę", "zabawę" (termin zapożyczony z muzyki) i to jeszcze jak na złość austriackiemu 
okupantowi drwiącemu z comedii dell'arte jako teatru pospólstwa, przeznaczonego dla regazzi - „dzieci”, „młodzieży”, może nawet „służby”.

To, co Agamben usiłuje wykazać w książce będącej, co zresztą sugeruje sam tytuł, literacko-filozoficznym odpowiednikiem rysunków i fresków Tiepola, to istnienie pewnego istotowego podobieństwa filozofii i komizmu (bardzo zresztą specyficznie rozumianego). Wskazuje już na to obrany przez Włocha cytat z Plutarcha otwierający dziełko. Antyczny, grecki pisarz przywołał w nim Sokratesa, który - jak go barwnie przedstawił - „filozofował, żartując, kiedy popadło", nie oddzielając sztywno czasu przeznaczonego na uczone dysputy od beztroskiego otium.

Książka, mimo niewielkich rozmiarów, podzielona jest na cztery części. Pierwsza z nich wprowadza czytelnika w problematykę - przywołuje postać Pulcinelli, a także wspomniane okoliczności powstania cyklu dzieł Tiepola poświęconego tej postaci. Agamben - i tu znów aluzja do Sokratesa - czyni to, przeplatając swój wywód fikcyjnym dialogiem między Pulcinellą a swoim twórcą. Ten sposób prowadzenia filozoficznej narracji, nieco rozbijający kompozycję tekstu, powraca w książce kilkakrotnie.

Filozofia, zdaje się przekonywać w tej części włoski filozof, „ma coś wspólnego zarówno ze śmiechem, jak i z płaczem" (s. 18). Jej doświadczeniem staje się niemożność wypowiedzenia istnienia dwóch fenomenów: języka oraz świata. Trawestując słynne słowa Wittgensteina „O czym nie można mówić, o tym trzeba milczeć" na Agambenowską modłę, można by rzec: „O czym nie można mówić, nad tym trzeba, jednocześnie, zapłakać oraz to wyśmiać". Symbolicznym obrazem staje się tu przywoływany przez Agambena fresk Bramantego Heraklit $i$ Demokryt, na którym płaczący Heraklit oraz śmiejący się Demokryt spoglądają jednocześnie na glob ziemski. Demokryt „,́mieje się z szaleństwa ludzi, którzy, podobni do atomów poruszających się bez celu, gonią na próżno za bezsensownymi celami; Heraklit natomiast płacze z powodu przemijalności rzeczy ginących w rzece stawania się" (s. 20). Język Pulcinelli nie tyle komunikuje, co poprzez grę słów i dwuznaczność wypowiedzi odsłania według Agambena istotę komedii - sprawia, że niemożność posługiwania się językiem staje się komiczna, budzi śmiech.

Część druga, która rozpoczyna się od kwestii etymologicznych związanych z etymologią imienia Pulcinelli, jest próbą uchwycenia tego, czym w istocie jest ta postać. W odróżnieniu od postaci tragicznej, która zawdzięcza swą nazwę temu, że ponosi winę, za którą los skazuje ją na określoną karę, w przypadku postaci komicznej, jaką niewątpliwie jest Pulcinella, na pierwszy plan wysuwa się jej charakter, êthos. Trudno w odniesieniu do niej mówić o tym, czy jej postępowanie jest moralne, czy nie - postępowanie Pulcinelli wynika wyłącznie z charakteru postaci, a jej zabawne czyny i gesty, tzw. lazzi, nie mają żadnego większego znaczenia dla akcji. 
Pulcinella to zatem jednocześnie postać rzeczywista i maska komiczna, rozumiana jako zbiór pewnych cech, którą może nałożyć dowolna postać sceniczna. „Nie jest czymś, a jedynie jak” (s. 67), i przez to „nie może zdjąć maski, ponieważ pod nią nie ma żadnej twarzy" (s. 78). Jest typem, a nie substancjalną indywidualnością „hybrydą unikatowości i ogólnikowości, indywidualnym rysem, który staje się zasadą seryjnej produkcji" (s. 79). Agamben, analizując tę postać, znowu sięga po preferowaną przez siebie kategorię: strefę niezróżnicowania (zona di indifferenza), to jest swoiste miejsce, topos, gdzie zatracają się wszelkie cechy dystynktywne między poszczególnymi fenomenami czy indywiduami. Niczym aktor, który przywdziewając maskę, tak mocno się z nią utożsamia, że gra oraz życie właściwie stają się jednym i tym samym.

Rozdział trzeci to kontynuacja rozważań o masce-postaci oraz aktorze - od czasów antycznych po nowożytność - a zwłaszcza o relacji między jednym a drugim. Agamben przypomina o niezależności komedii dell'arte od tekstu pisanego: jej aktor nie recytuje roli; improwizując, wciela się w życie i maskę postaci, którą przyszło mu odegrać. Życie Pulcinelli nie ogranicza się do odegrania pewnej konkretnej roli, lecz jest improwizacja, która - i tu kolejne idée fixe włoskiego filozofa - stanowi czystą potencjalność. Pulcinella na rysunkach Tiepola jest ukazany jako pełniący wiele zawodów (od drwala po kucharza), jednak pozostaje „zasadniczo bezczynny" (s. 130). Jest jak morze z fikcyjnego dialogu między Pulcinellą a Leibnizem kończącego rozdział „wieczna, nieodwracalną możliwością" (s. 134).

Rozdział czwarty, bodajże najbardziej filozoficzny z całego dziełka, otwiera zaczerpnięta z Państwa Platona opowieść o Erze, w której to grecki filozof $w$ barwny sposób opisuje naukę o metempsychozie, to jest wędrówce dusz i powtarzaniu cyklu życia moralnego. Jest to, zdawałoby się, kolejna erudycyjna dygresja bez większego znaczenia dla całości wywodu, jednak cel tej filozoficznej aluzji okazuje się zgoła inny. Służy bowiem filozofowi do zobrazowania tego, czym w istocie jest charakter - „tym, co pozostaje nieprzeżyte w każdym życiu” (s. 140).

Życie ludzkie rozumiane jako bios, wypadkowa zdarzeń i czynów, stanowi dla włoskiego filozofa scenę, na której najlepiej uwidacznia się różnica między tragedią a komedią. Różnica ta to nic innego jak sposób, w jaki - niczym dusze czekające na wyrok Ananke z mitu Platona - człowiek wchodzi w relację z „nieprzeżytym, to jest ze swoim charakterem”. Losem bohatera tragicznego staje się jego charakter wyrażony poprzez czyny, w komedii zaś na odwrót. Czyny zdają się nie manifestować niczego poza błazenadą i śmiesznością. W żadnym z tych przypadków, jak zauważa Agamben, charakter nie zostaje przezwyciężony.

Być może pewną wskazówka, jak uczynić egzystencjalny pożytek z tego, co w ludzkim życiu pozostaje nieprzeżyte, jest postać Pulcinelli, przynajmniej tej z fresków i rysunków Tiepola, niezwiązanej z żadnym 
bios, a więc będącej - w pewnym sensie - czystą potencjalnością. „Pulcinella - próbuje przekonać czytelnika Agamben - jest bezceremonialnym pożegnaniem z wszelkim charakterem, potrafi on przeżywać nieprzeżyte, nie traktując go jako losu ani nie naśladując go na modłę komiczną" (s. 148).

W tym sensie, jak się zdaje, należałoby traktować zaproszenie Agambena, przyglądającego się Pulcinelli niczym rokokowy malarz, jako swoistą medytację nad życiem jako takim. Wyraża się ona na kartach dziełka, chyba najbardziej osobistego ze wszystkich książek Agambena (kto wie, czy książka nie nosi śladów autobiografii), nierzadko za pomocą metafor, które wydają się filozoficznymi odpowiednikami technik malarstwa iluzjonistycznego, Filozof - po końcowych dywagacjach nad charakterem - stwierdza, że żyć dobrze to nic innego jak zrozumieć własną niemożność życia. Jakkolwiek enigmatycznie może to brzmieć. Wreszcie posuwa się do osobliwego stwierdzenia: „Pulcinella to ja” czy raczej „Pulcinella to my”. I oto, chcąc nie chcąc, rokokowy fresk Tiepola staje się lustrem.

Dawid Winctaw

Uniwersytet Mikołaja Kopernika, Toruń

ORCID: 0000-0002-0738-4057

e-mail: dwinclaw@doktorant.umk.pl 